Goodhead / Legon Journal of the Humanities (2017) 30-45

DOI:https://dx.doi.org/10.4314/lih.v28i1.4

\title{
The Discourse of Sustainable Farming and the Environment in Bessie Head's When Rain Clouds Gather
}

\author{
Dokubo Melford Goodhead \\ Formerly Assistant Professor of Interdisciplinary Studies at Spelman College, \\ Atlanta, Georgia, USA. Currently an Independent Researcher \\ dmdgoodhead@gmail.com
}

\section{Submitted: August 12, 2016 / Accepted: March 23, 2017 / Published: May 31, 2017}

\begin{abstract}
Starting with her pioneering novel, When rain clouds gather (1968), Head has left behind an impressive body of eco-literature. In this debut novel, Head tackles some of the most pressing problems of the environment as they affect the lives of poor rural dwellers in Botswana trying to leave hunger and poverty behind and gain a foothold in modernity and self-sufficiency with respect to the basic amenities of existence. Head's novel gives a global dimension to this project that unambiguously gestures toward a cosmopolitan ecocriticism.
\end{abstract}

Keywords: environment, sustainable farming, ecocriticism, cosmopolitan ecocriticism, postcolonial ecocriticism

\section{Introduction}

The need for sustainable agriculture and environment, which Bessie Head (1968) portrays in her novel, When rain clouds gather, has become increasingly urgent in a world that is now universally regarded as under the threat of apocalyptic-scale disasters from humanity-induced changes to the climate. In Moore and Nelson's Moral ground: Ethical action for a planet in peril (2010), for example, over eighty-five prominent persons including President Barack Obama, the Dalai Lama, and Archbishop Desmond Tutu come together to make an appeal for saving the planet. The earth and, in a broader sense, Nature have always been of interest to the literary artist. For example, the ancient Greek poet, Theocritus, is credited with inaugurating the pastoral form in which the simplicity of country life and humanity's happy co-existence with Nature are celebrated. In the Idylls, Theocritus contrasts this simple and joyous existence of humanity with an urban life, ridden with problems and anxieties. Theocritus's nostalgia for rural life is carried even further by Virgil, who in the Georgics depicts a golden age where everything was healthy and in abundance vis-à-vis humanity's subsequent lapsarian loss of that idyll.

However, for Virgil, humanity's descent from the bliss of the golden age also meant a fall into the prosaic world of work, the adoption of the ethos of responsibility, and the reproduction of culture in order to adapt to a fallen world that now required humans to work for their very sustenance and survival. Nonetheless, in the Georgics, Virgil still celebrates rural life and Nature in the way Theocritus did in the Idylls, hence the designation of the former by the classical scholar David Ferry (2005) as "the pastoral of hard work" (p. xvii).The "fall" into labor and culture notwithstanding, most societies lived fairly harmoniously with Nature until the Industrial Revolution and unregulated capitalism. While capitalism has created unimaginable wealth and lifted hundreds of millions of people out of poverty, capitalism, when unregulated, thrives on the use of Nature as a perceived inexhaustible source of raw materials that should be maximally exploited for the most profit. The result of this unbridled 
exploitation of Nature by a few is the imperilment of life for all, hence the near-universal call for the earth's sustainability. In regions of the earth where droughts rise to the proportion that Virgil describes in the plague at the end of the third section of the Georgics and make life unbearably difficult for rural dwellers, the call for a sustainable earth is even more urgent. Head lived in one of such regions of the earth, Botswana, and her representation of rural life and the struggle of its wretchedly poor villagers to scrap out an existence in the face of constant drought and disastrous farming practices that make life even tougher for them and the environment puts the novel in the category of what Leo Marx (2000) has called the complex pastoral. In the novel, as in Head's other literary works set in rural Botswana, for example, Maru (1971), A question of power (1973), and The collector of treasures (1977), drought constitutes an ever-present backdrop against which she explores the difficult lives of the poor rural dwellers, whom she consistently calls the "people with no shoes", within a cosmopolitan discourse of sustainability of the environment and the empowerment of the "shoeless".

Pastoral novels, such as When rain clouds gather, that underscore humanity's intimate connection to the environment, how human activities affect it, and how it in turn affects humans are increasingly being classified as ecoliterature whose critical appraisal is referred to as ecocriticism. Glotfelty (1996) has defined ecocriticism as "the study of the relationship between literature and the environment" (p. xvii). Expanding on the definition, she writes: "Ecocriticism takes as its subject the interconnections between nature and culture, specifically the cultural artifacts of language and literature. As a critical stance, it has one foot in literature and the other on land; as a theoretical discourse, it negotiates between the human and the nonhuman" (p. xix). As Buell (1995) reminds us, ecocriticism, the belief that the fate of the earth and that of humanity are intertwined and that we should be proactive in maintaining its wellbeing in the face of rapid industrial and technological advancements following the Industrial Revolution, has been in existence for a long time. In The machine in the garden, for example, Marx examines the $19^{\text {th }}$ century debate in the West on what technology would do to Nature, subsequent to the visible deleterious effects of the Industrial Revolution on the wildernesses and the countryside. However, in spite of these early concerns about the impact of technology on the environment, the environment has not fared any better because technology has been used to exploit it for maximum profit without regard for its wellbeing. It is into this breach that ecocriticism has stepped, assuming greater clarity in the wake of ecology and increasing natural and environmental crises. Head is a bold, pioneering ecoliterary writer, who uses the pastoral to explore the concept of sustainability in a region of the earth where pre-industrial agriculture, disastrous farming practices, poverty, droughts that sometimes rise to apocalyptic levels, and the imperative of raising the shoeless out of hunger intersect. In the novel, Head stresses how science and technology could be used to promote the sustainability of the environment and the wellbeing of the rural dwellers who make their living off the land.

\section{Sustainability: Dissent and Consensus}

The concept of sustainability or sustainable development is a widely debated one and draws very sharp reactions. Nevertheless, I argue that the concept remains the most useful in helping us to imagine our role as human beings in the context of our interdependence with the environment. As I would show from the works of several prominent critics of the term, their dissatisfaction with the term actually arises from its initial definition by the World Commission on Environment and Development (WCED) (1987), as development that "meets the needs of the present without compromising the ability of future generations to meet their needs" (p. 7). However, it is useful to keep in mind the caution of Kirsten Halsnaes and Anil Markandya (2002) that there are several hundred alternative definitions of the concept (p.2). Nevertheless, most critics take their cue from the WCED definition. While some critics argue that the concept, as defined by the WCED, is vacuous, fails to give proper guidance on what should be done to rescue the earth, and does not hold anyone accountable, others contend that it creates the erroneous impression that science and technology can be used to keep the resources of the earth flowing in perpetuity. These criticisms are outlined in varying degrees in Newton and Freyfogle (2005), Davies (2010), and Hayden (2010) and have been superseded, to a large extent, in the responses 
of the UN and various world bodies that followed the WCED report. Noteworthy too is the inability of critics to wholly abandon the concept. Unable to dismiss it, they often end up suggesting useful ways to modify it to incorporate their criticism. Even where the critics have turned to alternative concepts, a careful examination of these concepts is very likely to underline the necessity of the concept of sustainability.

In "Sustainability: A dissent" (2005), Newton and Freyfogle remark that there is an ambiguity in who is doing the sustaining in the WCED definition and that the ambiguity only disappears when the concept is applied to matters such as agriculture or development. Only then, they argue, does it become clear that human beings are the ones doing the sustaining. They imply, however, that nonhuman forces could be the sustaining agent if we modify our actions in ways that allow these forces to maximally shape the future (p. 25). The authors ought to have explained the term "modification" to show whether it means that we should alter our lifestyles or the way we use science and technology since the type of far-reaching changes that would make it possible for non-human forces to maximally shape the future are today practically impossible without the intervention of science and technology. Newton and Freyfogle concede this key role of science when they write: "When we deal with nature we deal with real places, yet inevitably we are guided in our dealings by our mental understandings. Indeed, this mind-narrative gap is a big reason why we use science. Science brings the real and the mental into closer alignment by improving our understanding of the real" (p. 28).

Therefore, in the matter of who is doing the sustaining, it is important that we do not lose sight of the critical role of the human factor, since humans have long moved past basic existence in the state of nature into a modernity that is driven by human-authored science and technology. However, in spite of this centrality of the human factor, Newton and Freyfogle are right when they say that sustainability can only be achieved when the roles that both human and non-human forces play are fully taken into consideration.

Newton and Freyfogle attribute the idea that "we can aggressively manage nature so long as we are prudent and scientific in doing so" (p. 25) to the late conservationist Gifford Pinchot, whose vision of conservation they see as limited because it gives us the impression that we "could have it all" (p. 25). In the Pinchotian view of the environment, they argue, we could "use better science and economics to get nature's resources flowing in perpetuity" (p. 25). They conclude that, "Pinchot had little to say about nature's overall limits or about the wisdom of bending our lives to respect nature's time-crafted ways" (p. 25). Their reading, then, of the WCED definition of sustainability is that it has been influenced by Pinchot's thesis. If we are to move away from disaster, they contend, our green turn should be toward Aldo Leopold whose construct of "land health," "include[s] the soils, waters, plants, animals, and people" (p. 26), is more appropriate. In the Leopoldian vision of conservation, the emphasis is "on the ecological whole, sometimes accentuating the biotic parts, at other times the processes that knit them together" (p. 27). In this vision, humanity and the environment operate in an organic system where there is a "focus on soil fertility in terrestrial systems and on the maintenance of intact, efficient systems for the cycling of nutrients from the soil, through plants and animals, and back to the soil" (p. 27). This is clearly an elaboration of the concept of sustainability where human actors must still take the sort of decisions as well as act in ways that bode well for the environment and for humanity. Thus, in the end, the authors return to the concept of sustainability: "If sustainability were to gain stature as an overall vision of human life on Earth, land health might properly stand as an independent viable component of it" (p. 30). In effect, except the notion of land health is stripped of its human component as outlined in the Leopoldian definition, what Newton and Freyfogle have elaborated in their dissent and their preference for the alternative construct of land health is no more than an elaboration of the concept of sustainability.

Like Newton and Freyfogle, Davies (2010) also has reservations about the concept and like them he is unable to escape it. However, unlike Newton and Freyfogle, who, as conservationists, are well acquainted with the genealogy of the concept, Davies, who is not trained in the field, is forced to rely solely on the 1987 WCED definition. This greatly narrows his imagination in the use to which the concept can be put. He notes its practice in the West in the form of the new culture of energy saving 
and recycling of waste material. However, in spite of this new culture of environmental consciousness, he believes that the orientation toward sustainability is utopian (p. 263). In spite of this antipathy toward the concept, Davies sees its usefulness and the need for its retention if it is reformulated to dispel "its desire for permanence" (p. 264).

Davies raises a valid point that there is a desire for permanence in the concept if sustainability is understood to mean a perpetual flow of raw materials through the use of science and technology. As Newton and Freyfogle have correctly stressed, this belief does not take the earth's carrying capacity into account. A good example is ozone layer depletion resulting from excess greenhouse gases in the atmosphere. In a similar manner, we can talk of the pollution of marine ecosystems and excessive use of forest resources or terrestrial and marine wild life. In these instances, it would be wise, as Newton and Freyfogle suggest, to bend our lifestyle to suit Nature's ways. Nevertheless, in spite of Davies's skepticism about recycling and the concept of sustainability, we should not lose sight of the ways in which science and technology do indeed help us to turn waste material into reusable material, find and exploit renewable forms of energy, like solar energy, and reduce pollution to the environment. It is worth emphasizing that even restoration projects like the successful reforestation efforts of the late Nobel Peace Prize laureate Wangari Maathai, in Kenya, need good science and technology. Yet another example is the rapid and substantial decline in the global consumption of chlorofluorocarbons (CFCs) between 1987 and 1996 as a result of the 1985 Framework Convention for the Protection of the Ozone Layer and the 1987 Montreal Protocol (Simonis \& Bruhl cited in Hayden, 2010, p. 365). There is therefore a real and practical sense in which the concept of sustainability is not based on nostalgia for the future analogical to the nostalgia we have in the pastoral form of writing as Davies argues. And, yes, it is indeed true that the actions we take today can ensure the future of generations yet unborn, for if we are able to avoid the catastrophes associated with, for example, global warming, who is to say that we have not succeeded in not only securing the present but the future too? Sustainability is, therefore, neither a nostalgia for the future nor a retreat into utopia.

Therefore, Davies's recourse to nostalgia appears pretentious. Citing Susan Stewart, he writes that the nostalgic "seeks to imagine an alternative kind of narrative in which desire is not marked by the necessity of absence. In the same way, the narrative of human progress that is kept within the bounds of sustainable development will free itself from the threat of irreversible loss, guaranteeing for itself the constant presence of its own material basis" (p. 266).

If sustainability means that our desire does not consider loss, especially irreversible loss, the whole edifice that the concept has erected will collapse since the threat posed by the rapidly encroaching absence of resources, whose supply we once took for granted, constitutes a hard ineluctable reality. When, for example, smog fills the air as a result of carbon emissions and other chemical effluents from automobiles and industrial activities, it is not nostalgia for the past or the future that compels us to pass laws to sanitize the air and free ourselves of the smog. It is because we are confronted with a reality whose consequences could be quite devastating if we do not take action. To imagine sustainable development, then, as a "hermetic withdrawal or even a form of nihilism, transforming life into a deathly stasis" (p. 267), is, therefore, the real flight into a hermetic world since our bodies force us to experience the environment in ways that make it impossible for us to take flight into the past or the future. We are reminded of this in a water supply polluted by an oil spill or in a land where the rivers and streams have dried up because all the trees have disappeared. Therefore, as embodied beings, we live in a material world that we must constantly engage.

\section{African Literature, the Turn toward Ecocriticism, and Bessie Head}

In his now influential survey of the field of ecoliterature and ecocriticism in Africa, Slaymaker (2001) makes the impossible claim that "the African echo of global green approaches to literature and literary criticism has been faint" (p. 132). However, to his credit, Slaymaker makes the pertinent observation that "Black African writers take nature seriously in their creative and academic writing" (p. 132). Interestingly, however, while Slaymaker makes this pointed observation on the ecoliterary writing and criticism "in the white literary establishment in South Africa" (p. 132), nowhere does he 
mention the remarkable ecoliterary work of Bessie Head, perhaps the most important ecologyconscious writer of the continent then and now.

Nonetheless, Slaymaker's essay made enough of an impression on the scholar Sonja Darlington (2007), whose article, "The Significance of Bessie Head's Response to 'The Call of the Global Green," "is, in her own words, a direct response to Slaymaker's article. Darlington seeks to bring Head's "influential voice on the environment" from the margins to the center by redefining "her environmental concerns for the international public" (pp. 97-98). Additionally, Darlington's interest in Head is "to re-engage ecocritics and ecoliterature writers to keep the earth's precarious sustainability as their primary focus of conversation with an inclusive global community" (p. 98). Darlington's two concerns, sustainability and global inclusivity, are major themes in When rain clouds gather, which demand a cosmopolitan ecocritical reading as opposed to a postcolonial ecocritical reading, as is now the norm. An example of this norm is Elspeth Tulloch's (2012) article, "Husbandry, agriculture and ecocide: Reading Bessie Head's When clouds gather as a postcolonial georgic."

Tulloch claims inspiration for her article from Darlington. In Tulloch's ecocritical reading of the novel, she turns to the georgic mold with regard to the postcolonial issues that the novel raises and Head's status as an outsider in Botswana(p. 138). However, Head's outsider status barely features in Tulloch's reading of the novel except as the contentious outsider/insider binary with respect to two of the novel's major characters, Makhaya and Gilbert, which opposition Tulloch stretches to the point of essentialism. Appropriately, Tulloch places the novel in the tradition of the pastoral, drawing inspiration from the Georgics. However, she starts off on a problematic note when she makes reference to Virgil's use of outside knowledge in his famous poem about humanity's fall from a golden age of abundance and absence of labor into culture. She does this in order to establish an analogical comparison to Head's use of the agricultural expertise of the English expatriate, Gilbert, and Makhaya, a South African refugee. She then uses the outsider/insider binary to critique the narrative of development in the novel but this ultimately proves to be a dead end since in order to undermine the narrative she invokes two conceptual frameworks, imperial georgic, which turns the novel on its head, and postcolonial georgic, which relies on a very problematic reading of a passage in the novel. The passage actually presents overwhelming evidence in favor of the opposite of Tulloch's reading of it. In the end, Tulloch turns to a mystical resolution of the plot and the representation of Head's peasants as some kind of noble savages.

The novel cannot be an imperial georgic since its focus on Gilbert's work with the villagers of Golema Mmidi is on the one hand not about empire's children going to the colony to strip people of their land, which they then exclusively use for growing cash crops to the detriment of the people and, very often, to the land itself, and on the other is actually a critique of such imperial expropriation of land and exploitation of the colonized. We see a classic example of the imperial georgic in Maathai's discussion of colonial Kenya in Unbowed (2006) where she talks of how the colonial settlers in colonial Kenya displaced native trees in favor of nonnative trees in the Aberdare Forest for commercial purposes. Maathai writes: "These trees grew fast and strong and contributed to the development of the newly emerging timber and building industry" (p. 39). But this "development" came at a huge cost to the land and to the people. Maathai further notes "They eliminated local plants and animals, destroying the natural ecosystem that helped gather and retain rainwater" (p. 39). In the end, "underground water levels decreased markedly and, eventually, rivers and streams either dried up or were greatly reduced" (p. 39).

Head's novel is a critique of this kind of spurious development in favor of direly needed sustainable development to get the shoeless out of perpetual hunger into enduring sustenance through the restoration of the fertility of the land. In art, as in life, several factors usually stand in the way of such a noble goal. She writes that Gilbert's work had "destroyed Matenge's [the tyrannical local chief] lucrative cattle-speculating business overnight" (p. 47). Matenge exploited his people in collaboration with the white colonial settlers, who made enormous wealth on the backs of the poor peasants from cattle speculation. Head writes: "The cattle-speculating monopolies were in the hands of a few white traders..." (p. 47), who became "rich at the expense of the people" (p. 46). She revisits the issue with 
greater elaboration in the story of the faith-healing priest in The collector of treasures (1977). Moreover, she is unambiguous about the status of the novel as a counter-imperial georgic. Again and again, she represents Gilbert as doing his work in opposition to both the colonial settlers who make their enormous wealth from the ill-fed cattle of the peasants and the feudal chiefs, who use their enormous power over the people to exploit them. At a poignant moment of the novel as an anti-imperial georgic, she writes: "One day, these colonial authorities were so unfortunate as to pick up a rumor that all was not well with Gilbert in the village of Golema Mmidi. They wrote him a pally letter: 'Why not come and join us, old boy?' He sent back an unprintable reply” (p. 42). The novel is, therefore, a counter-imperial georgic and is instead about cosmopolitan relationships.

There are a number of passages in the novel on which Tulloch bases her reading and they are worth a closer look. There is the fencing incident. Tulloch talks of studies about the detrimental effects of fencing on the rural poor and wild life but is silent on the contexts in which fencing may be detrimental to wild life and the rural poor (p. 141). If a few people, colonial settlers and local elite, fence off huge swaths of land for themselves at the expense of the rural peasant it would be condemnable. This is a very contentious issue and Head presents an analogical situation in the novel to address it (pp. 36-38). The land in the community, she writes, is not meant to fall "into the hands of a few rich people" (p. 38). The first time Head introduces fencing in the novel is in the context of saving chickens from avian predators and raising a healthy and well-fed stock. The old man Dinorego provides the context: "There was my friend, Mma-Millipede, who had fifty-two fowls. They were wandering free, being eaten by the eagles" (p. 27). The old man took Mma Millipede to Gilbert, who advised her to build a coop fifteen feet by twenty-five feet and six-feet high and house one cockerel with fifteen hens. The old woman stopped losing her chickens to the eagles and became a successful poultry farmer (p. 27). There is a sense in which such details look pedestrian in a creative work but Head knew that she was dealing with real-life problems of hunger and backbreaking poverty and dispensed with fanciful metaphors for a creative detailing of daily existence and survival in one of the poorest places in the world at the time she was writing the novel.

The second time that Head brings up fencing, it is for the purpose of the scientific restoration of the land to its once fertile and bio-diverse state. She uses two brief juxtaposed passages to make this point economically. The old man Dinorego recalls a time "when the whole area had been clothed by waist-high grass and clear little streams had flowed all the year round. The pathways of the streams were still there but dry and empty now" (p. 37). The disappearance of the life-sustaining little streams and fertile land forced the people to abandon their villages. Accordingly, years later when Gilbert travels through the region, he encounters abandoned villages and an ocean of sand throughout the journey. However, having gone to England to study how to nurse the land back to health to make it arable, he comes to the conclusion "that only large-scale fencing of the land and controlled grazing would save the parts that had not yet become completely eroded and uninhabitable for both man and animals" (p. 38). To put the lie to the claim of the tyrannical local chief that he is a typical colonial settler who had fenced off the land for his own use, he takes the people to the fenced-off land to see the remarkable recovery of the land. Head writes: "All the old men could not but agree that they had not seen such grass in Golema Mmidi for a long time. He also took them to the cattle ranch where the same miracle had occurred" (p. 39). Writing in an ecocritical fashion, Head shows that the devastated land, like the human body when sick, needs favorable conditions to recover hence the need for fencing it. Context is, therefore, very important because in its absence, one could be led into wild speculations that would be wide off the mark.

Tulloch is critical of the narrative of development in the novel, even though Head shows throughout the novel that she is talking of the sustainable kind, and not the type that brings disaster to both the environment and the people living in it. As a result, Tulloch argues that the Turkish tobacco that Gilbert introduces into the community to help finance the restoration of the land and the agricultural projects is "a controlled form of species invasion introduced by neocolonial pressures..." (p. 144). Constrained by a postcolonial eco-critique that is clearly inadequate, at least as she uses it, to read the novel Tulloch in spite of acknowledging that Gilbert's goal is to use the sale of the tobacco to 
transform the village into an agricultural center of activity able to feed itself and supply the rest of the country with fruit and vegetables is constrained to dismiss Head's real-life oriented pragmatism with the words "invasion" and "neocolonial." If Tulloch were to be constrained more by a cosmopolitan eco-critique rather than a postcolonial critique the real question she would be asking is whether the tobacco plant is good for the land. Even though Tulloch points out the need for extra water for the tobacco and, therefore, the digging of a drainage pit in the compound of each woman involved in the project to capture rainwater, except for aesthetic concerns, Head presents the drainage pits as a temporary measure, to be replaced by a centralized source of water supply when the community generates enough money to build more than the one borehole servicing it (p. 114). The backbreaking poverty of the shoeless has to be factored into any kind of ecocriticism in ways that account for both the wellbeing of the land and the escape of the shoeless from hunger and poverty.

This is the crux of the developmental narrative in the novel and the work of Gilbert. He does not arbitrarily impose science and development on the land. He painstakingly tests his hypotheses, including the introduction of new species into the community, to determine their suitability for the land and the community (pp. 36-37). By the time we meet him, he has been conducting observations and experiments on the land for three years (p. 36). Consequently, what Head demonstrates in the novel is not ecological imperialism but crop migration, which is as old as the earth, as crops have migrated from one part of the earth to another by wind, water, insects, birds, animals, and human agency. Head astutely underscores this point by juxtaposing the plot that each woman uses to grow the tobacco in her compound to the plot she uses to grow her maize, a staple crop with origins in South America. Crops with origins in South America that have since become staple crops in Africa include the peanut and cassava. Head's project of sustainable farming is, therefore, one that is attuned to the needs of the environment as well as to the freedom of the millions of "shoeless people" all over rural Africa from hunger and poverty.

However, because Tulloch is committed to a postcolonial ecocritical paradigm, she is uncomfortable with Head's use of Gilbert, an English expatriate, to lead the project. Consequently, she reads into two passages in the novel that which is obviously not there. The first passage deals with the model village built by Paulina's little daughter. The child bases the model village on what she sees all around her, a village with no trees. Throughout this representative mini-narrative or mise-en-abyme (pp. 108-115), there is no place where Makhaya is presented as expressing reservations and uncertainty about the bio-diverse, sustainable agricultural work he is doing with Gilbert and the villagers as Tulloch argues (p. 144). Read in the context of the evidence presented by the passage, Makhaya's request to Paulina for permission to place a tree in the model village is an act of politeness and mirrors the greening of the village with plants and trees. As a matter of fact, at the end of the passage, Head writes of him: "[H]e was absorbed in studying the future needs of the tiny village..." (p. 115). Therefore, Gilbert's search for the most suitable spot to place the last of the trees that Makhaya has carved for the model village actually captures an essential aspect of the overall narrative - doing the most suitable thing for the environment and the villagers and not imposing things by fiat on either of them. It is why Gilbert does not arbitrarily place the tree anywhere but in the most suitable spot.

However, building on her problematic reading of the model village, Tulloch contends that Gilbert begins to experience serious doubts that lead him "to challenge his own developmental ambitions for the people and his role as agro-husband/developer" (p. 144). The passage Tulloch is talking about is bookended by the moment after he puts the last tree in the model village and is so ecstatic about how the real village would ultimately turn out to be (p. 114) and his feeling of great goodness about the country after engaging in a reflection on whether the actual motivation for the work is to enable the villagers "to catch up with the Joneses in the rich countries?" (p. 184). Therefore, if this reflection about superhighways and skyscrapers is juxtaposed to his ultimate goal that every household should have potable water and that the village should have palm trees, fruit trees, flower gardens (p. 114), be self-sufficient in food production, and supply fruits, vegetables, and the best grade beef to the rest of the country (p. 155), we immediately realize that the reflection is a way of reminding himself to focus on what really matters for the shoeless villagers. 
As already stated, it is a problem for Tulloch that Gilbert, a white Englishman, should be the initiator of the projects even though he is an Englishman with a cosmopolitan sensibility. She writes: "From a postcolonial perspective, it is problematic that the narrative situates the impetus for this renewed husbandry in outsider figures led by Gilbert, who represents Western science" (p. 143). Here, as elsewhere, Tulloch uses the anachronistic term "Western science" to pigeon-hole and discredit Gilbert's scientific work. When, however, she is talking about scientific work that supposedly discredits his work, the tag "Western" is omitted from the science. Since Tulloch's postcolonial perspective has a problem with Gilbert being a Westerner, she has to find a way of grounding the direly needed recuperation of the environment and the escape of the villagers from poverty in something that at least appears to rupture Gilbert's cosmopolitan identification with the villagers. To do so, she resorts to mysticism and the transformation of the villagers into noble savages. She writes about Gilbert's repeated losing of his way in the bush paths of the village in the following words: "For all his science - his purported enlightenment -- Gilbert cannot surpass the local people's hidden (to him) knowledge, symbolised here as darkness" (p. 143). This needless mystification of what is otherwise pedestrian knowledge gathered from a lifelong use of the footpaths and bushes of the village turns the Tswana into noble savages, who possess a mystical knowledge of the footpaths and bushes in a way that is knowable only to them because they are Tswana by birth. Tulloch continues: "The solution to the problems of the land must be locally generated, one specifically African," "one controlled by a higher, rurally sympathetic power" (p. 146). This power is a "mischievous, bored, distinct, overseeing presence above science" (p. 146). In the end, to resolve her opposition to Gilbert's sustainability-driven scientific project, Tulloch couches her recourse to mysticism in the postmodernist language of uncertainty in a manner that confers some kind of mystical fertility resulting from the marriage of Paulina and Makhaya on the land. She writes: "In assenting to take a husband, Pauline [sic] is 'settling into' or figuring the attitude needed for producing/finding food in the region's unpredictable environment, acknowledging the paradox that to settle here - in Botswana - is to accept the possibility of unsettledness" (p. 147). She goes further: "Their union bears the promise of fruit, so the narrative's rural God ordains" (p. 147).

In this final recourse to postmodernist uncertainty and mysticism to resolve the plot of the novel, Tulloch seems to be unaware that whenever Head brings God and the spiritual into her fictional work it is usually to deal with ethical and moral issues and that though she frequently juxtaposes it with the realities of the human condition, she never confuses her forays into the metaphysical realm with the hard realities of natural situations that invite scientific inquiry and resolution. This is clearly evident in her story about an old female herbal healer of the village of Bodibeng, whom fellow villagers accuse of using witchcraft to kill children and sick woman. The old herbalist cures sickness through her knowledge of the medicinal properties of herbs not witchcraft. The paramount chief knows this as well as the fact that the villagers have conveniently made the old woman a scapegoat for their negligence in protecting their children from cold and pneumonia. He rightly turns the table on them by asking for the autopsy reports of the dead children and the dead woman (pp. 51-54). Another example is her short story, "Looking for a rain god" (1977). We see this turn to the metaphysical and the spiritual to deal with ethical and moral issues and their juxtaposition to the realities of everyday life most prominently in her novels, Maru and A question of power.

\section{The Problem with Postcolonial Ecocriticism}

Tulloch's problematic resolution of the novel through mysticism and postmodernist uncertainty are in many ways anticipated in Vital's articles $(2008 ; 2005)$. In the 2008 article, Vital takes some time to reflect, along with Graham Huggan, Rob Nixon, and Dominic Head on the necessity of a rapprochement between ecocriticism and postcolonial critique. However, in Vital's view, it is only Dominic Head that takes note of the difficulties in bringing about such rapprochement and the one who gave him the insights into the topic for his own article. Both he and Dominic Head wonder whether such rapprochement is possible, knowing that while ecocriticism is grounded in ecology postcolonial critique is informed by a poststructuralist understanding of language with its seeming 
denial of a physical ground of meaning (p. 89). According to Vital, Dominic Head resolves this impasse in his reading of Michael $K$ by attending to the "intimations of the material" in the novel, "the literal, that the dominant code elaborating ideas of 'textuality' cannot absorb, Head can then read the novel as being about ecology, necessarily extratextual" (p. 89). This is unsatisfactory because in postructuralist discourse, nothing escapes language and language, according to this view, invests everything, even ecology, with both uncertainty and an endless deferral of meaning. Head's other insight, which actually enables Vital to propose a materialist understanding of discourse, is actually more appropriate to Vital's project. Vital writes:

Discourse stands in arbitrary but also power-laden relation to the material world but not all discourses are equal in guiding societies to interact well with earth's biophysical processes or to address inequities among human populations and the attendant suffering and meager life-opportunities (p. 90).

In his 2005 article, Vital identifies the appropriate discourse for an African ecocriticism as one rooted in the concept of environmental justice, which he thinks in the specific case of South Africa, enables the ecocritic to talk about the country's apartheid past, modernity and those it has left behind, as well as South Africa's place in the contemporary global capitalist system. Therefore, according to him, South African environmentalism has to be unrepentantly anthropocentric (p. 298). However, Vital realizes that an unrepentantly anthropocentric environmentalism will introduce conflicts between the needs of those that South Africa's colonial past as well as the current global capitalist system has left behind and the needs of the environment. Moreover, Vital had earlier come to the conclusion that any worthwhile African ecocriticism must "enable social worlds to find more equitable, sustainable, and healthy ways of inhabiting their place - as well as strengthen historical self-understanding" (p. 87). But an unrepentantly anthropocentric ecocriticism cannot in the same breath talk of sustainability. As a matter of fact, an unrepentantly anthropocentric ecocriticism will find good company in unregulated capitalism, which would supposedly provide more profit as well as more jobs and material goods for society. Vital resolves this impasse by asking that we view ecology as actually acting in our own interest because "it provides a vision of kinship with other living and non-living beings that are part of the material systems that make possible our embodiment" (p. 305).

Vital's article, while underlining the inescapability of the concept of sustainability in addressing the environmental problems of our time, also shows, as does Tulloch's article, that there is a disparity between ecocriticism and postcolonial criticism. Moreover, as we have seen from Tulloch, while it is true that in decentering the Western subject, postcolonial critique aims for a more inclusive world it loses its salience if this is stretched to breaking point and makes any meaningful cooperation between the West and post-colonial Africa impossible. But the magnitude of the problems facing contemporary Africa and the peril, which the planet as a whole faces from contemporary environmental problems, can only be addressed by a cosmopolitan vision. This, I argue, is the ideal vision that most readers encounter in Head's novel.

\section{Toward a Cosmopolitan Ecocriticism of When Rain Clouds Gather}

The concept of cosmopolitanism has been attributed to Diogenes, who when he was asked where he came from answered that he was a citizen of the world (Kleingeld, 2012, p. 2). Diogenes "held that all human beings are owed certain positive duties of hospitality and brotherly love, as if they were common citizens of the world" (Brown \& Held, 2010, p. 4). Brown and Held give a comprehensive definition of the concept that is quite useful for this article. They write:

In its most basic form, cosmopolitanism maintains that there are moral obligations owed to all human beings based solely on our humanity alone, without reference to race, gender, nationality, ethnicity, religion, political affiliation, state citizenship, or other communal particularities (p. 1). 
One of the most important explorations of the concept with regard to the environment is Patrick Hayden's article, "The Environment, Global Justice and World Environmental Citizenship" (2010). Like many scholars who have written about the environment, Hayden takes his cue from the 1987 WCED definition of sustainability. Similarly, like Newton and Freyfogle and Davies, Hayden takes issue with the WCED definition and, again like them is unable to escape the concept of sustainability in the end, especially as he follows the development of the concept from its first intimations in the earlier UN Conference of the Human Environment (UNCHE) of June 71972 to its fuller development in the Rio Declaration on Environment and Development (1992). Unable to rid himself of the concept, Hayden incorporates it into his construct of sustainable justice, an amalgam of sustainability, social justice, and environmental justice. Like Vital, Hayden admits that the concept of environmental justice, upon which he builds his notion of sustainable justice, is anthropocentric but like Vital he too resolves this impasse by noting the interdependence between human beings and the environment. He writes that "its concern with human health and wellbeing is grounded in the recognition that the quality of human life is inseparable from the quality of the supporting ecosystems upon which human life depends" (p. 360).

Hayden imagines a global approach with a cosmopolitan vision of environmental crises. $\mathrm{He}$ argues that since countries in the developed world have contributed more to the global environmental crisis than developing economies and are at the same more economically prosperous and technologically advanced, they should do more to help countries in the developing world with their environmental problems in order to foster greater justice and improvement in the quality of life of people everywhere on the planet (p. 360). In this regard, Hayden talks of " the emergence of a global civil society in which networks of actors spanning different levels and different sectors of society are linked by their shared concern for the environment and human development, which results in local groups taking action based on globally embedded ideas" (p. 367). Taken together, the concepts of cosmopolitanism and sustainability provide the most resilient tools to resolve the global environmental crisis and its negative effect on local communities. They also have the capacity of freeing the shoeless from hunger and poverty, and ushering them into a sustainable modernity.

Eilersen (1995), Head's biographer, tells us that the portrait of the English expatriate, Gilbert, is actually based on the Englishman Vernon Gibberd, an agricultural worker whom Head met in Serowe. Eilersen quotes Head as saying of the Englishman, "I liked the ideas of the man ... and how he had fitted himself into the position of very poor people" (p. 85). Head transposes this into the novel when she writes of Gilbert's identification with shoeless villagers, treating them "as though they were his blood brothers" (p. 24) when he could have acted as the colonial officer, George Appleby-Smith, or the colonial cattle speculators. The cosmopolitan, as we have seen, regards the entirety of humanity as his/her kindred. The outsider/insider binary, which postcolonial critics, such as Tulloch and CamineroSantangelo (2014) impose on the novel, is therefore an artificial one. Gilbert, by adoption and cultural immersion, becomes a Tswana. Talking about Gilbert to Makhaya, when the latter newly arrives in the village, the old man says:

Just as I take you as my own son, so do I take Gilbert as my own son, which fact surprises me, since he is a white man and we Batswana do not know any white people, though some have lived here for many years. Many things caused me to have a change of mind. He can eat goat meat and sour-milk porridge, which I have not known a white man to eat before. Also, whenever there is trouble he comes to me and says, 'Dinorego, should I stay here? (p. 27).

Even though there are white settlers amongst them, the Tswana "do not know" any white people because the white settlers are the colonial type, who have erected distinct boundaries between them and the Tswana. The two, therefore, live in two parallel worlds. When, however, Gilbert, a cosmopolitan, enters the village, he collapses the two worlds into one and becomes not a settler but a fellow villager with the villagers, a reality which the old man formally recognizes by adopting him as 
his son.

Moreover, Head lived and worked on a similar farm like the one she writes about in the novel. In a letter to Randolph Vigne that he later published with Head's other letters in A gesture of belonging (1991), Head talks of translating her experience on the farm into a novel (p. 21). Additionally, Head was well acquainted with the history of the Tswana, parts of which she publishes in Serowe: Village of the rain wind (1981). In this brief history of the Tswana are some of the key issues which she writes about in the novel. Serowe, like Golema Mmidi, is often a drought-stricken place. She writes of the town, "During my ten-year stay here, the two or three seasons when it rained for a whole month in one long, leaden downpour were so exceptional and stunning that I cannot even describe them. I am more familiar with the rain pattern of drought years" (1981, p. x).

The natural and human-made environmental problems that Head represents in the novel, like the projects of reversal of loss and renewal of the land, are therefore translated from a reality that spills out of the fictional world of the novel to circle back into the real. Contrary, then, to Tulloch's request that Gilbert's agricultural scientific project be read as metaphor it should in fact be read as being firmly rooted not only in reality but also in the history and the environment of the Tswana, as continuation of the project of Tshekedi Khama. Head writes that following in the footsteps of his father, Khama the Great, Tshekedi Khama, ruler of the Tswana, transformed the age-group regiments of the tribe into self-help regiments to build community projects. While the efforts of Khama the Great in using age groups could be described as ad hoc, his son transformed them into permanent self-help regiments. Head stresses what Tshekedi Khama did as revolutionary: "His time was famed for educational progress, and the ideal of self-help was introduced into Serowe life long before it became an international byword or necessity" (p. 76). She adds: "I worked on self-help projects in a much later period and was amazed at the old men who would come and peer at the work and join in the pickdigging. When I commented on it, people replied: 'They used to work like that with Tshekedi. My father who passed away helped to build Masokola School, you know"' (p. 76). Another participant in Tshekedi's self-help projects, Lekoto Digate, an eighty-six-year old retired cattleman, tells Head that the participants in the projects built "schools and roads and dams for watering cattle" (p. 93). The idea of self-help projects was therefore not new to the Tswana.

The shoeless people are the ones who drive the project to bring modernity into their land as a kind of sustainable pastoral, that is, to restore the environment to what it used to be in order to usher them into a sustainable modernity. It is because the villagers cannot do this alone that the development project is located within a cosmopolitan framework. The shoeless villagers give the two outsiders, Gilbert and Makhaya, hospitality, a cosmopolitan act. Instead of turning the hospitality into an exploitative one, as in a colonial relationship, the two return the hospitality. In what could be considered a classic cosmopolitan relationship with the people, they turn themselves into insiders, abolishing artificial differences between them and their hosts. The village becomes their home but since they were previously urban dwellers, they have seen modernity up-close and noticed the difference that science and technology could make to humanity's existential problems in the village. This is why Gilbert goes to England to get the requisite knowledge he needs to make an intervention in the tradition of Khama the Great and his son, Tshekedi Khama. This is one of the instances in the novel where Head unambiguously signals the idea that the contents of the novel spill outside of the novel into the real world and that even though the story is presented as fiction, she is dealing with material conditions outside of the text.

The march toward and into modernity is therefore not a roughshod one over the land and the people. The land would be returned to the bio-diverse pastoral environment it used to be and this restoration will in turn improve the lives of the shoeless villagers and enable them to adopt sustainable ways of farming and raise their livestock with the benefit of the advances in science and technology. Head differentiates this development project from the work of the colonial agriculturists and the getrich-quick schemes of the colonial cattle speculators (p. 42; p. 46). In one, the outside agent is a cosmopolitan agent and in the other, the outside agent is an imperial agent working for the exploitative interests of self and empire. The two sets of people come into the land by different methods. The 
imperial agent enters the land through the guns of empire and seizes the land with the guns. The cosmopolitan agent comes as a visitor seeking hospitality and service to the community. The one sets up settler communities and builds an unbridgeable chasm between themselves and the host community. The other goes into the community and lives and works with their hosts to confront the existential problems of the community as members of the community. This is why the old man Dinorego tells Makhaya that before Gilbert the villagers had not known any white person even though there are white settlers living close by.

The work of empire and its commercial agents is dictated by the needs of empire and the material aggrandizement of imperial agents, not by what is good for the colonized or the environment. Maathai has shown us how this occurred in colonial Kenya. We encounter another example in the Belgian Congo in Conrad's Heart of darkness, where Conrad's Marlowe recounts the needless and reckless abuse of the environment: "A heavy and dull detonation shook the ground, a puff of smoke came out of the cliff, and that was all. No change appeared on the face of the rock. They were building a railway. The cliff was not in the way or anything; but this objectless blasting was all the work going on" (pp. 31-32). In contrast, we have seen the rigorous regimen of experiments that Gilbert in his role as an agricultural scientist undertakes to ensure that the scientific innovations and new species of plants that he is introducing into the community are good for both the environment and the people.

\section{Conclusion}

No nation can go it alone in solving the current global environmental crisis. Poor countries, especially, need help in tackling their environmental and food production problems, hence the call for a cosmopolitan ecocriticism. Head's novel is about a cosmopolitan ethic of place, the sustainable pastoral, and the sustainability of the shoeless. According to the 2015 Human Development Report, "In 2014 the richest 1 percent of the world's people owned 48 percent of global wealth, a share that could rise to more than 50 percent in 2016" (p. 75). In stark contrast,"[i]n 2013 about 370 million people in developing country regions were working but living on less than $\$ 1.25$ a day" (p. 75). Also, in 2014-2016, 780 million people in developing countries were suffering from chronic hunger. 90 million of this number were children under the age of five (p. 75). In a recent article that he did on climate refugees from Mali, Niger, and the Gambia, Somini Sengupta (2016) writes: "They do it because the rains have become so fickle, the days measurably hotter, the droughts more frequent and more fierce, making it impossible to grow enough food on their land." He adds that in 2016 alone, "more than 311,000 people have passed through Agadez on their way to either Algeria or Libya, and some onward to Europe...." Can these devastations be reversed? Yes, some of it at the least can be reversed. According to the 2015 Human Development Report, "Between 2000 and 2010 the global net loss in forest fell from an average of 8.3 million hectares a year to an average of 5.2 million hectares a year thanks to afforestation and the natural expansion of forests" (p. 74).

As scholars of cosmopolitanism, such as Hayden, Brown and Held have noted, this reversal is only likely to come about if the rich nations of the world who have greater scientific and technological resources put those resources at the disposal of developing nations. Hayden puts such interventions under the concept of environmental justice. However, environmental justice projects even when they are undertaken successfully are very often what a handful of people undertake for others. Sustainability, on the other hand, is something we all do to ensure our wellbeing and the wellbeing of the ecological community, locally, nationally, regionally, and globally. Sustainability places agency in the hands of all human actors, asking them to take responsibility for the fate of the environment in which they live. Makhaya's blowing up of the earth with dynamite in order to reach down to deep subterranean water levels with borehole technology therefore takes a new meaning from the one Tulloch gives to it. The 2015 Human Development Report reminds us that, "Water scarcity affects more than 40 percent of people around the world" (p. 74). If people in poor and drought-stricken nations are to remain in their homelands instead of fleeing them, then, as Head writes in her novel, a cosmopolitan partnership between those who have the science and technology to bring about reversals to the damaged and deficient environments and those who need to use them to thrive in their homelands 
is the road that we, as humanity, must take. Worthy of note though is Head's suggestion that these cosmopolitan partnerships might even come about as a result of cosmopolitans, such as Gilbert, who turn themselves into technological migrants. The world is, of course, more familiar with economic migrants, whether of the individual type or imperial agents, who settle down in colonized territories and accumulate wealth for themselves and empire. Today, multinational companies often follow a similar path because all that matters to them is the profit they make from the host community. However, in a rapidly shrinking world where people are becoming more and more globally conscious and cosmopolitan minded, we are likely to find more technological migrants going, in the opposite direction, into communities where, like economic migrants, they put down roots and become part of the community, bringing along with them valuable scientific and technological knowledge to their new homelands to make it easier for the new homelands to deal with climate and environmental challenges.

The entire earth was once a pastoral environment. In Virgil's metaphoric reading of this natural history, the beginning was a golden age of abundance. There was no work because the means of sustenance were everywhere around us. However, we "fell" from that age into the age of work and culture. Our numbers expanded all over the earth and cities sprang up and the pastoral environment of the golden age was no longer guaranteed to us. It became something that we, as producers of knowledge and culture, must sustain if we are to live in harmony with Nature. This is the tradition in which Head has written her novel, complete with a flight of urban dwellers to the rural area, who must work with the rural poor in a spirit of cosmopolitanism to restore the fertility of the land and in doing so enable the rural poor to be self-sufficient. The shoeless, who have long looked from the outside at a modernity that has left them behind, can now be participants in it. However, it is a modernity not of reckless exploitation of the land but one based on the knowledge that there is an intimate interdependence between the wellbeing of the land and the wellbeing of those who dwell on it. 


\section{References}

Brown, G.W. \& Held, D. (Ed.). (2010). The cosmopolitan reader. Cambridge, UK: Polity Press.

Buell, L. (1995). The environmental imagination: Thoreau, nature writing, and the formation of American culture. Cambridge, MA: The Belknap Press of Harvard University Press.

Caminero-Santangelo, B. (2014). Different shades of green: African literature, environmental justice, and political ecology. Charlottesville, VA : University of Virginia Press.

Conrad, J.(1989).Heart of darkness. R.C. Murfin (Ed.). Boston, MA: Bedford Books of St. Martin's Press. (Original work published 1899)

Darlington, S. (2007). The significance of Bessie Head's response to 'The call of the global green.' Journal of the African Literature Association, 1(2), 97-107.

Davies, J. G. H. (2010). Sustainable nostalgia. Memory Studies, 3(3), 262-268.

Eilersen, G. S. (1995). Bessie Head: Thunder behind her ears: Her life and writing. Portsmouth, NH: Heinemann.

Ferry, D. (Ed. \& Trans.). (2005). Introduction. In Virgil, The georgics of Virgil (pp. xi-xx). New York, NY: Farrar, Straus and Giroux.

Gifford, T. (1999).Pastoral. London, UK: Routledge.

Glotfelty, C. (1996). Introduction. In C. Glotfelty \& H. Fromm (Ed.), The ecocriticism reader: landmarks in literary ecology (pp. xv-xxxvii). Athens, GA: The University of Georgia Press.

Gray, S. (2008). "Introduction.” When rain clouds gather (pp. i-xiv). Harlow, UK: Heinemann.

Hayden, P. (2010). The environment, global justice and world environmental citizenship. In G. W. Brown \& D. Held (Ed.), The cosmopolitan reader (pp. 351-372). Cambridge, UK: Polity Press.

Head, B. (1991). A gesture of belonging. R. Vigne (Ed.). London, UK: Heinemann.

Head, B. (1971). A question of power. New York, NY: Pantheon Books.

Head, B. (1972). Maru. London, UK: Heinemann. (Original published 1971)

Head, B.(1981). Serowe: Village of the rain wind. Oxford, UK: Heinemann.

Head, B. (1993). The cardinals. Oxford, UK: Heinemann.

Head, B. (1977). The collector of treasures. Oxford,UK: Heinemann.

Head, B. (1968). When rain clouds gather. New York, NY: Simon and Schuster.

Kleingeld, P. (2012). Kant and cosmopolitanism: The philosophical ideal of world citizenship. Cambridge, UK: Cambridge University Press.

Maathai, M. M. (2006). Unbowed. New York, NY: Alfred A. Knopf.

Markandya, A. \& Halsnaes K. (2002). Climate change and sustainable development; an overview.In A. Markandya \& K. Halsnaes (Eds.), Climate change and sustainable development: Prospects for developing countries (pp. 1-14). London, UK: Earthscan Publications.

Moore, K. D. \& Nelson M. P. (Eds.). (2010). Moral ground: Ethical action for a planet in peril. San Antonio, TX: Trinity University Press.

Marx, L.(2000).The Machine in the garden: Technology and the pastoral ideal in America.

Oxford, UK: Oxford University Press. (Original work published 1964)

Newton, L. N. \& Freyfogle, E. T. (2005). Sustainability: a dissent. Conservation Biology, 19 (1), 23-32.

Sengupta, S. (2016, December 15). Heat, hunger and war force Africans onto a 'Road of Fire.'

The New York Times. Retrieved from http://www.nytimes.com/interactive/2016/12/15/

world/Africa/Agadez-climate-change.html.

Slaymaker, W. (2001). Ecoing the Other(s): The call of global green and black African responses. PMLA, 116 (1), 129-144.

Theocritus. (1947). Idylls. R. C. Trevelyan (Trans.). Cambridge, UK: Cambridge University Press.

Tulloch, E. (2012). Husbandry, agriculture and ecocide: reading Bessie Head's When rain clouds gather as a postcolonial georgic. European Journal of English Studies, 16 (2), 137- 150.

United Nations Development Program (UNDP). (2015). The 2015 human development report. Retrieved from hdr.undp.org/sites/default/files/2015_human_development_report.pdf. 
Vigne, R. (Ed.). (1991). A Gesture of belonging: Letters from Bessie Head, 1965-1979. London, UK: Heinemann.

Virgil. (2005). The georgics. D. Ferry (Ed.). New York, NY: Farrar, Straus and Giroux.

Vital, A. (2005). Situating ecology in recent South African fiction: J. M. Coetzee's The lives of animals and Zakes Mda's The heart of redness. Journal of Southern African Studies, 31 (2), 297-313.

Vital, A. (2008). Toward an African ecocriticism: Postcolonial ecology and "Life \& Times of Michael K." Research in African Literatures, 39 (1), 87-106.

World Commission on Environment and Development (1987). Our common future. Oxford, UK: Oxford University Press. 